\title{
СИНТЕЗ 1,3-ДИЗАМЕЩЁННЫХ МОЧЕВИН И ТИОМОЧЕВИН, СОДЕРЖАЩИХ ТЕРПЕНОИДНЫЙ ФРАГМЕНТ
}

\author{
М.Х. Аббас Саиф, Д.А. Питушкин, А.А. Вернигора, В.В. Бурмистров, \\ Г.М. Бутов
}

Волгоградский государственный технический университет, 400005, Россия, г. Волгоград, пр. Ленина, 28.

DOI: 10.19163/MedChemRussia2021-2021-252

E-mail:buto@volpi.ru

Для расширения массива данных об энантиомерной специфичности растворимой эпоксидгидролазы человека (sEH), представляет интерес биоизостерическая замена (1,7,7-триметилбицикло[2.2.1]гептан-2-ильного) фрагмента на (1,3,3-триметилбицикло[2.2.1]-гептан-2-ильный), получаемый из фенхона. Фенхон является изомерным камфоре терпеноидом и в природе содержится в таких растениях как Foeniculum vulgare Mill. (фенхель), Pimpinella anisum L. (анис), Anethum graveolens L. (укроп) и других.

Синтезированы 1,3-дизамещённые мочевины и тиомочевины, содержащие в своей структуре оптически активную бициклическую липофильную группу природного происхождения по реакции ( $R$ и $S)$-1,3,3-триметилбицикло[2.2.1]гептан2-амина (полученного из терпеноида фенхона) с ароматическими изоцианатами и изотиоцианатами с выходами до $88 \%$ и 87 \% соответственно.

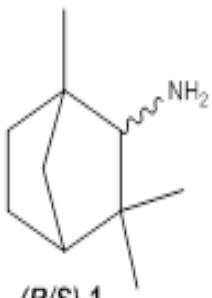

$(R / S)-1$

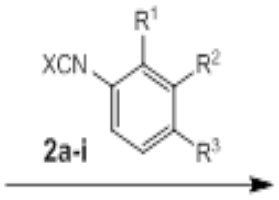

$\mathrm{Et}_{2} \mathrm{O}, \mathrm{Et}_{3} \mathrm{~N}$

$R^{1}=R^{2}=R^{3}=H, X=O(3 a), R^{1}=F, R^{2}=R^{3}=H, X=O(3 b), R^{2}=F, R^{1}=R^{3}=H, X=O(3 c), R^{3}=F$,

$R^{1}=R^{3}=H, X=O(3 d), R^{1}=C l, R^{2}=R^{3}=H, X=O(3 e), R^{2}=C l, R^{1}=R^{3}=H, X=O(3 f), R^{2}=F$, $\mathrm{R}^{1}=\mathrm{R}^{3}=\mathrm{H}, \mathrm{X}=\mathrm{S}(\mathbf{3 g}), \mathrm{R}^{3}=\mathrm{F}, \mathrm{R}^{1}=\mathrm{R}^{2}=\mathrm{H}, \mathrm{X}=\mathrm{S}(\mathbf{3 h}), \mathrm{R}^{2}=\mathrm{Cl}, \mathrm{R}^{1}=\mathrm{R}^{3}=\mathrm{H}, \mathrm{X}=\mathrm{S}(3 \mathbf{i})$

Образование мочевин протекает с приемлемым выходом при проведении реакции в диэтиловом эфире. Исходные изоцианаты и изотиоцианаты хорошо растворимы в эфире, как и 1,3,3-триметил бицикло[2.2.1]гептан-2-амин, поэтому применение ДМФА в качестве растворителя не требуется. S-изомер соединения 1 вводился в реакцию в виде гидрохлорида, а R-изомер в виде гидросульфата. Соответствующие гидрохлорид и гидросульфат не растворимы в эфире, однако при добавлении триэтиламина происходит образование гомогенной системы.

Работа выполнена при финансовой поддержке Российского фонда фундаментальных исследований (грант № 19-33-60024). 